\title{
Genetic variability in the endophytic fungus Guignardia citricarpa isolated from citrus plants
}

\author{
Chirlei Glienke-Blanco, Carlos Ivan Aguilar-Vildoso, Maria Lúcia Carneiro Vieira, \\ Paulo Augusto Vianna Barroso and João Lúcio Azevedo \\ Department of Genetics, Escola Superior de Agricultura "Luiz de Queiroz", \\ Universidade de São Paulo, Piracicaba, São Paulo, Brazil.
}

\begin{abstract}
During some phases of of their life-cycle endophytic fungi colonize plants asymptomatically being found most frequently inside the aerial part of plant tissues. After surface disinfection of apparently healthy leaves from three varieties of mandarin orange and one tangor, and after incubation on appropriate culture medium, 407 fungal isolates were obtained, giving a total infection frequency of $81 \%$. No fungal growth was observed from disinfected seeds, indicating that fungi are probably not transmitted via seeds. Of the fungal isolates, $27 \%$ belonged to the genus Guignardia, with 12 isolates being identified as Guignardia citricarpa Kiely, which is described as a citrus pathogen. The isolates were variable in respect to the presence of sexual structures and growth rates. Most of the isolates produces mature asci, supporting the hypothesis that they are nonpathogenic endophytes, which recently were identified as G. mangiferae. High intraspecific genetic variability (an average similarity coefficient of 0.6 ) was detected using random amplified polymorphic DNA (RAPD) markers generated by seven different primers. The highest similarity coefficient (0.9) was between isolates P15 and M86 and the smallest (0.22) between isolates P15 and $\mathrm{C} 145$. These results did not allow us to establish an association between genetic similarity of the fungal isolates and the citrus varieties from which they were obtained.
\end{abstract}

Key words: citrus, endophytes, genetic variability, Guignardia citricarpa, mandarin, RAPD.

Received: December 15, 1999; accepted: July 22, 2002.

\section{Introduction}

Endophytic fungi asymptomatically colonize plant tissues during some phases in their life cycle (Petrini, 1991). Although the nature of their interaction with hosts is still not well understood, it has been established that in many cases the relationship can be symbiotic, antagonistic or even neutral. Some of these microorganisms are relatively easy to isolate as they grow in simple culture media and can be obtained after external disinfection of plant tissues. Investigations related to endophytic microorganisms isolated from several plants and their tropical hosts have recently increased, due to the increasing importance of fungi in biological control and the ongoing search for pharmacologically active compounds (Pereira et al., 1993; Breen, 1994; Rodrigues, 1994; Rodrigues and Dias-Filho, 1996; Miles et al., 1998; Strobel and Long, 1998; Pereira et al., 1999; Azevedo et al., 2000; Pinto et al., 2000). Little is known about the microbial endophytic community of citrus

Corresponding author: Chirlei Glienke-Blanco. Departamento de Genética, UFPR, Caixa Postal 19071, 81.531-990 Curitiba, PR, Brazil. E-mail: cglienke@garoupa.bio.ufpr.br.
(Araujo et al., 2001) and the possible impact of endophytes on yield and, especially, on the control of citrus plant diseases, making the isolation and study of these microorganisms important for morphological, physiological and genetic studies.

The research reported in this paper was designed to isolate and characterize the endophytic fungal population of some Citrus species and showed that Guignardia citricarpa is one of the fungi most frequently present in citrus. Because of its importance in phytopathology and the present lack of genetic data, we also assessed the genetic diversity of $G$. citricarpa isolates using random amplified polymorphic DNA (RAPD) markers and cytological analysis.

\section{Materials and Methods}

\section{Fungal isolates}

To isolate the endophytes, 85 apparently healthy leaves and 200 seeds were collected from three varieties of mandarin orange (varieties Poncã and Cravo of Citrus reticulata $\mathrm{cv}$. Blanco and variety Mexerica of C. deliciosa 
cv. Tenore and one tangor (variety Murcote, a hybrid of $C$. reticulata $\mathrm{cv}$. Blanco and C. sinensis cv. Osbeck) growing at the Sylvio Moreira Citriculture Center, Agronomic Institute of Campinas, Cordeirópolis, São Paulo, Brazil. These plants were approximately 11 years old. Fungi were isolated using the method of Petrini (1986) i.e. leaves were surface sterilized by immersion in $70 \%(\mathrm{v} / \mathrm{v})$ ethanol for $1 \mathrm{~min}$, sodium hypochlorite $3 \%$ (v/v available chlorine) for 4 min and washed in $70 \%$ ethanol for 30 seconds, after which they were rinsed several times in sterilized distilled water and cut into five 5-7 mm fragments in a sterilized chamber and transferred in serial order to plates containing the complete culture medium (CM) of Pontecorvo et al. (1953). Tetracycline was added to the medium at $100 \mu \mathrm{g} / \mathrm{mL}$ to inhibit bacterial growth and the plates incubated at $28{ }^{\circ} \mathrm{C}$ for a maximum of 2 weeks. The seeds received similar treatment but half of the seeds used were cut apart before plating.

Isolates were purified, coded, and,when possible, identified by standard mycological methods . Guignardia citricarpa isolates P15, P45, P210 (from Poncã), C145, C224, C320 (from Cravo), X68, X80, X171 (from Mexerica) and M86, M131, M216 (from Murcote) were subjected to morphological and RAPD analyses.

\section{Identification and cytology}

The isolates were cultured on CM, potato dextrose agar (PDA) and malt extract agar (MEA) as appropriate. Cytological identification and analysis of the isolates were carried out by observing the reproductive structures (sexual and asexual), using optical microscopy and the Giemsa staining technique of Furtado (1968), as modified by Luna (1985), and lactophenol (Onions et al., 1981).

\section{Preparation of DNA samples}

Genomic DNA was obtained according to the methodology described by Raeder and Broda (1985), with modifications. Isolates were grown in agitated $\mathrm{CM}$ broth for 4 days at $28^{\circ} \mathrm{C}$. The resulting mycelia were filtered, ground in liquid nitrogen and dissolved in $4 \mathrm{~mL}$ of Lysis buffer (200 mM Tris- $\mathrm{HCl} \mathrm{pH} \mathrm{8.0,} 250 \mathrm{mM} \mathrm{NaCl}, 25 \mathrm{mM}$ EDTA, $1 \%$ SDS) for each gram of mycelia. The mixture was incubated for $15 \mathrm{~min}$ at $70^{\circ} \mathrm{C}$ and then extracted once each with phenol, phenol:chloroform (1:1) and chloroform. The DNA was precipitated with $100 \%$ ethanol and pelleted by centrifugation at 12,000 $\mathrm{g}$ for $20 \mathrm{~min}$. The recovered DNA was washed with $70 \%$ ethanol and, after drying, dissolved in TE buffer (10 mM Tris-HCl, $\mathrm{pH} 7.6$; $1 \mathrm{mM}$ EDTA, $\mathrm{pH}$ 8.0). RNA contamination was eliminated by incubating the samples with RNAse $(50 \mu \mathrm{g} / \mathrm{mL})$ at $37^{\circ} \mathrm{C}$ for one hour.

\section{RAPD reactions}

After optimizing amplification conditions, the reagent mixture was made up to $25 \mu \mathrm{L}$ with autoclaved Milli-Q water containing $50 \mathrm{ng}$ DNA, $2.5 \mu \mathrm{L} 10 \mathrm{x}$ buffer
(Pharmacia), $4 \mu \mathrm{L}$ dNTP ( $0.2 \mathrm{mM}$ for each), $2 \mu \mathrm{L}$ primer $(0.4 \mu \mathrm{M}), 0.4 \mu \mathrm{L}$ Taq polymerase (2.0 units, CENBIOT/ RS, Brazil) and $5 \mu \mathrm{L} 7.5 \mathrm{mM} \mathrm{MgCl}_{2}$ (to bring the final magnesium concentration to $3 \mathrm{mM}$ ) and overlaid with mineral oil. After initial denaturation at $92 \mathrm{C}$ for $4 \mathrm{~min}$, DNA amplifications were performed for 40 cycles of one minute at $92{ }^{\circ} \mathrm{C}$, one minute and $30 \mathrm{~s}$ at $37^{\circ} \mathrm{C}$ and two minutes at $72{ }^{\circ} \mathrm{C}$. The cycles were followed by a final extension of $3 \mathrm{~min}$ at $72{ }^{\circ} \mathrm{C}$. The primers (Operon Technologies, Alameda, CA) used were OPX6 (ACGCCAGAGG), OPX8 (CAGGGGTGGA), OPX11 (GGAGCCTCAG), OPX12 (TCGCCAGCCA), OPX14 (ACAGGTGCTG), OPX17 (GACACGGACC) and OPX19 (TGGCAAGGCA).

Jaccard similarity coefficient (Jaccard, 1908) and the unweighted pair-group method with averages (UPGMA) were used to analyze genetic variability and a dendrogram constructed using the NTSYS-PC program (Rohlf, 1988) with the Winboot program (Yap and Nelson, 1996) being used for bootstrap analysis.

\section{Results}

Isolation

We obtained 407 fungal isolates from a total of 433 leaf fragments, the genera most frequently observed being Guignardia (Phyllosticta) (27\%) and Colletotrichum $(60 \%)$. The remaining $13 \%$ of isolates was made up of representatives of several other genera, and mainly consisted of sterile mycelia which meant that they were not identified in this study. The overall leaf infection frequency calculated from the number of infected leaf fragments divided by the number of leaf fragments transferred to culture medium $(349 / 433)$ was $81 \%$. There was no fungal growth on the seeds placed on culture media, indicating that the endophytes probably did not colonize (and thus were not transmitted by) mandarin or tangor seeds.

\section{Identification and cytology}

Twelve of the Guignardia isolates were identified as being Guignardia citricarpa Kiely (anamorph: Phyllosticta citricarpa Van der aa), known to be the causal agent of Black Spot disease in citrus. These isolates were then characterized by their reproductive structures and submitted to molecular analysis using RAPD. The structures observed and their average size in $\mu \mathrm{m}$ were: pycnidia (124.03 x 198.51), pycnidiospore (5.93 x 10.83), appendage (7.90), pseudothecium (244.90), ascus (9.70 x 58.20), ascospore (5.77 x 13.00), spermogonium (97.97) and spermatium $(1.55 \times 6.79)$. These measurements agree with the data reported in the literature for G. citricarpa (Van der aa, 1973; von Arx, 1974; Punithalingam, 1974; Sivanesan, 1984).

Morphologic details of some of the fungal structures are shown in Figure 1 (a-j). The G. citricarpa isolates had multinucleated hyphae and uni, bi, tri and multinucleated pycnidiospore (Figure 1, $\mathrm{f}-\mathrm{j}$ ) and binucleated sexual spores 

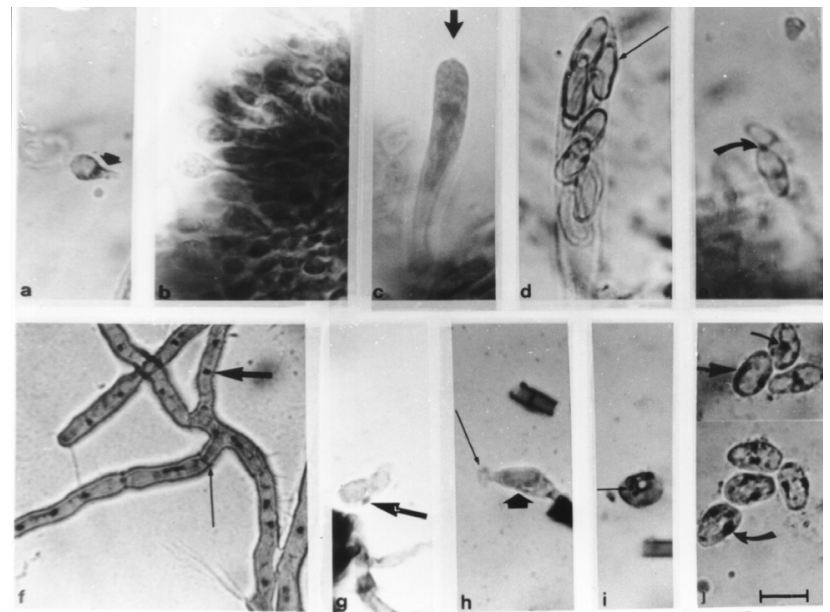

Figure 1 - Guignardia citricarpa. Lactophenol staining (a-e.): (a) pycnidiospores, the characteristic appendix (arrow) of the genus Phyllosticta; (b) conidiophore; (c) young ascus, mucilaginous cap (arrow); (d) mature ascus, 8 ascospores (arrow); (e) ascospore, the mucilaginous cap (arrow) of the two spore ends is a characteristic of the genus Guignardia. Giemsa staining (f-j): (f) septa (thin arrow) and multinucleated hyphae (thick arrow); (g) uninucleated ascospores (arrow); (h) binucleated ascospore, one nuclei (thick arrow) cap (thin arrow); (i) pycnidiospore (multinucleated); (j.) pycnidiospores, uninucleated (thin arrow) and binucleated (thick arrows). $B a r=10 \mu \mathrm{m}$.

(Figure 1h). The spermatial form, although rare, was also observed. The 'X-spores' were found in a halter form, slightly curved and bigutulated at the ends (Kiely, 1948 and Van der aa, 1973). The isolates showed differences in growth rates (data not shown) needing approximately four weeks to develop mature pseudothecium. However, isolate M86 showed higher production of mature asci after only a week of growth at $28{ }^{\circ} \mathrm{C}$ in the dark on PDA enriched with yeast extract. The presence or absence of sexual reproduction was also variable, asci being present in nine $G$. citricarpa isolates but absent in three.

\section{RAPD}

The seven primers generated 156 bands (Figure 2) of which 143 were polymorphic, giving a monomorphism rate of about $8 \%$. These data were used to construct a similarity matrix and a dendrogram (Figure 3). Bootstrap analysis indicated that the 12 isolates were grouped into two welldefined clusters with a $\mathrm{P}$ value superior to $95 \%$, where $\mathrm{P}$ is the percentage appearance of a cluster in 2000 dendrograms generated by bootstrap sampling.

\section{Discussion}

After Giemsa staining we found variability in the number of nuclei in asexual and sexual spores of $G$. citricarpa, with approximately half of them becoming binucleated or trinucleated after one or two divisions of their original nucleus (Figure 1f-j). However, for the typespecies for this genera, Janex-Favre et al. (1993) found that young pycnidiospores (Phyllosticta bidwelli) are uninucleated.

By visual inspection some of our isolates, mainly isolate M86, showed a higher growth rate and earlier sporulation compared to others ; this accentuated growth and maturity rate differs from that reported in the literature for pathogenic Guignardia species. The citrus pathogen most frequently described in the literature is G. citricarpa (Frean, 1966; Kellerman and Kotzé, 1977; Tsai, 1981;

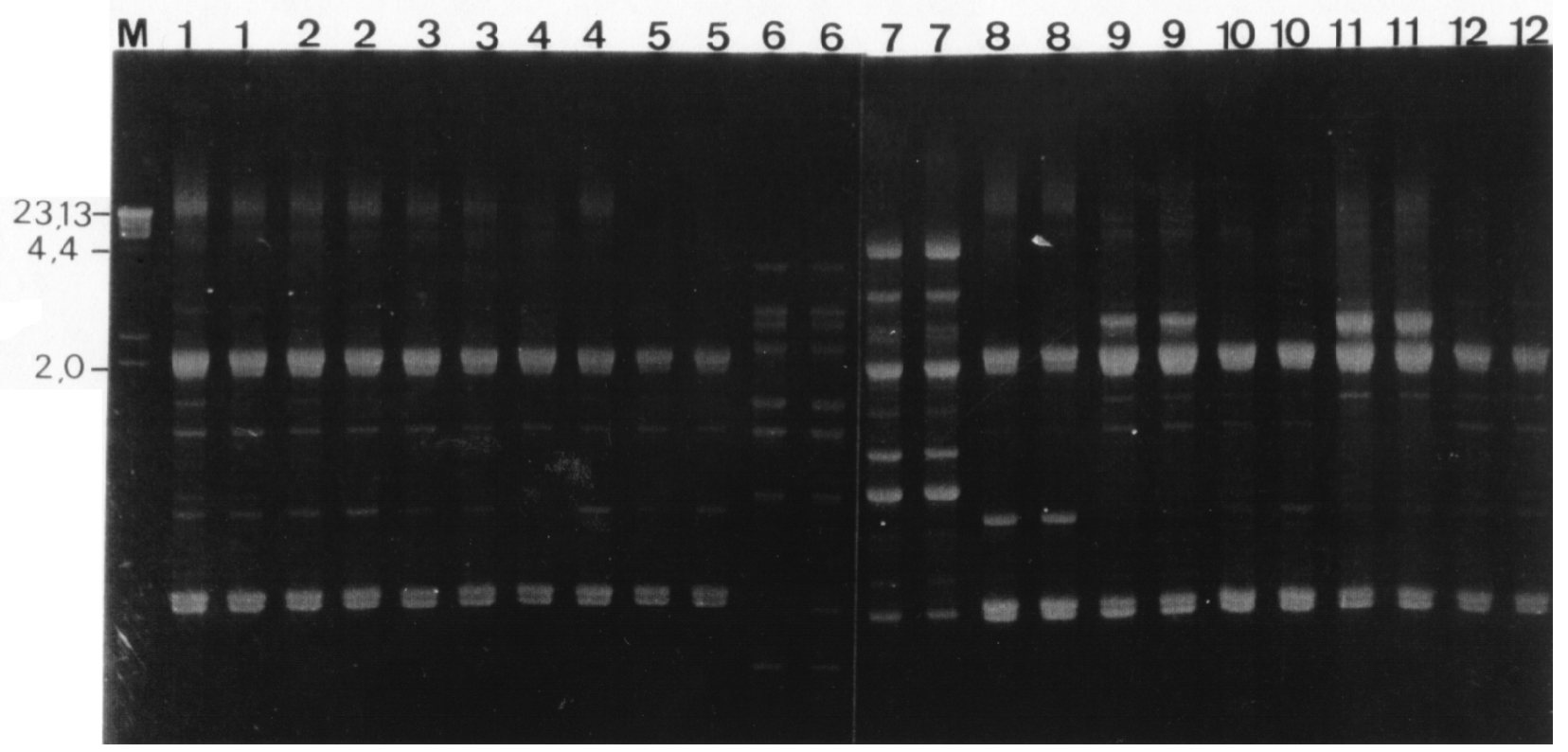

Figure 2 - Polymorphism obtained by amplification of Guignardia citricarpa DNA using primers OPX11 (a) and OPX12 (b). Isolates: $1=$ P15, $2=$ P45, $3=\mathrm{X} 68,4=\mathrm{X} 80,5=\mathrm{M} 86,6=\mathrm{M} 131,7=\mathrm{C} 145,8=\mathrm{X} 171,9=\mathrm{P} 210,10=\mathrm{M} 216,11=\mathrm{C} 224,12=\mathrm{C} 320 . \mathrm{M}=$ size marker, Hind III $/$ Eco R1 digested Lambda DNA. $\mathrm{B}=$ control reaction without DNA template. 


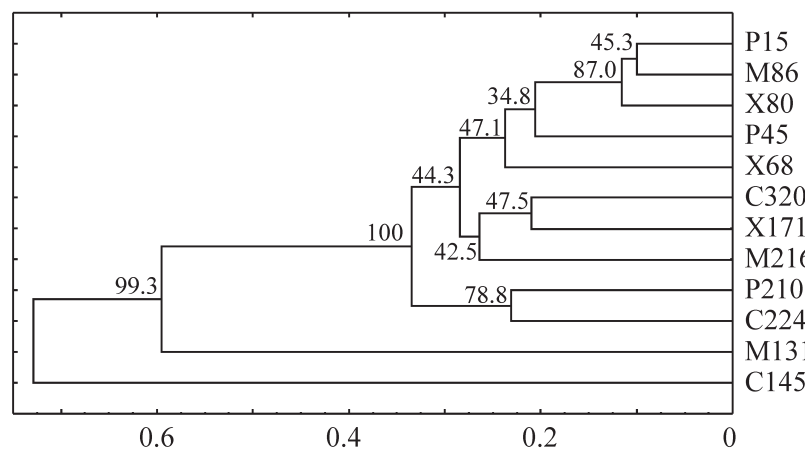

Figure 3 - Genetic distance dendrogram showing the relationships between Guignardia citricarpa isolates P15, P45, X68, X80, M86, M131, C145, X171, P210, M216, C224 and C320. The numbers to the left of the clusters are P values and the abscissa Jaccard's similarity coefficient.

Robbs and Bittencourt, 1995), but isolates of this fungus have been described in countries where symptoms of citrus black spot have not been observed and also from asymptomatically infected leaves from twenty plant families. When we collected our isolates only lemon trees (the most susceptible and first to show the disease in orchards) showed symptoms of this disease, no mandarin trees being infected.

McOnie (1964) reported the latent occurrence in citrus (and 13 other hosts) of Guignardia isolates (which he called Guignardia sp.) easily confused with G. citricarpa, although McOnie's isolates did not produce symptoms of black spot disease. When McOnie compared the non-pathogenic isolates with pathogenic G. citricarpa (i.e. those producing black spot lesions) it was seen that in spite of their being morphologically identical they were physiologically and pathogenically different, McOnie's Guignardia sp. isolates producing asymptomatic infections, while the pathogenic isolates caused both symptomatic and asymptomatic infection. Furthermore, according to McOnie the phytopathogenic isolates seemed to infect only citrus while the non-pathogenic had a wide range of hosts.

It thus seems that there are two alternatives regarding our G. citricarpa isolates, firstly our isolates may be phytopathogenic but have remained latent in some mandarin plants or, that the isolates are non-phytopathogenic like those described by McOnie (1964). Recent results have shown that the second alternative seems to be the most appropriated one, being nonpathogenic isolates of $G$. citricarpa identified as G. mangiferae (Baayen et al., 2002)

The dendrogram generated by RAPD analyses (Figure 3) shows high intraspecific variability. According to bootstrap analysis, the majority of the isolates are grouped in a very definite cluster the internal structure of which could not be defined, although isolates M131 and C145 are distinguishable from each other as well as from the other isolates. Comparing Figure 3 with the citrus varieties from which the isolates were obtained showed no apparent association between the 12 isolates and the varieties from which they were isolated, e.g. isolates P15 and M86 had a high similarity coefficient of $90 \%$ but were isolated from different varieties while isolates M86 and M131 had a low with similarity coefficient of $38.8 \%$ but came from the same host.

We found no relationship linking morphology with the host plant or genetic similarities of the 12 isolates, which is similar to that which was found for Hirsutella rhossiliensis by Tedford et al. (1994) who found no link between morphology and pathogenicity. According to Petrini (1991), in some cases the high electrophoretic variability within one Phyllosticta species is apparently not reflected by corresponding morphological differentiation. Although Leuchtmann et al. (1992) have shown that, for Phyllosticta isolates, culture characteristics are similar in lines of different species these authors have also shown that the distribution of enzymatic phenotype in Phyllosticta species is related to the host, where each one of five Phyllosticta pseudotsugae hosts were infected by lines with distinct phenotypes not found in isolates of any other host species.

\section{Acknowledgments}

The authors thank Dr. Maria Helena P. Fungaro for her assistance with the RAPD analysis, Dr. Elza A.L.A. Lima for help in identifying the Guignardia isolates, Dr. Walter Maccheroni Jr. and Luciana B. Cerqueira for useful suggestions, Sylvio Moreira Citriculture Center/IAC for assistance in collecting material and the Brazilian agencies CNPq and FAPESP for financial support.

\section{References}

Azevedo JL, Maccheroni Jr. W, Pereira JO and Araujo WL (2000) Endophytic microorganisms: a review on insect control and recent advances on tropical plants. Electr. J. Biotechnol. v. 3, http://www.ejb.org/content/vol3/issue1/full/3/4.

Baayen RP, Bonants P.M.J., Verkley G, Carroll GC, van der Aa HA, Brouershaven IR van, Schutte GC, Maccheroni Jr W, Glienke-Blanco C and Azevedo JL (2002) Nonpathogenic isolates of the citrus blackspot fungus Guignardia citricarpa, identified as a cosmopolitan endophyte of woody plants G. mangiferae (Phyllosticta capitalensis). Phytopathol. 92:464-477.

Breen JP (1994) Acremonium endophyte interactions with enhanced plant resistance to insects. Annu. Rev. Entomol. 39:401-423.

Frean RT (1966) Physiological studies with Guignardia citricarpa Kiely, the cause of the black spot disease of citrus. South Afr. J. Agric. Sci. 9:777-793.

Furtado JS (1968) Basidial cytology of Exidia nucleata. Mycologia 60:9-15.

Jaccard P (1908) Nouvelles recherches sur la distribution florale. Bulletin de la Societé Vaudoise des Sciences Naturelles 44:223-270.

Janex-Favre MC, Parguey-Leduc A, and Jailloux F (1993) The ontogeny of pycnidia of Guignardia bidwellii in culture. Mycol. Res. 97:1333-1339. 
Kellerman CR and Kotzé JM (1977) The black spot disease of citrus and its control in South Africa. Proc. Internat. Soc. Citric. 3:992-996.

Kiely TB (1948) Preliminary studies on Guignardia citricarpa. N. sp.: The ascigerous stage of Phoma citricarpa McAlp. and its relation to black spot of citrus. Proc. Linn. Soc. N.S.W. 73:249-292.

Leuchtmann A, Petrini O, Petrini LE and Carroll GC (1992) Isozyme polymorphism in six endophytic Phyllosticta species. Mycol. Res. 96:287-295.

Luna EA (1985) Características citológicas e genéticas de linhas selvagens, mutantes e diplóides de Metarhizium anisopliae (Metsch.) Sorokin. Ph.D. Thesis, Universidade Federal do Rio de Janeiro, Rio de Janeiro. 260 pp.

McOnie KC (1964) The latent occurrence in Citrus and other hosts of a Guignardia easily confused with G. citricarpa, the citrus black spot pathogen. Phytopath. 54:40-43.

Miles CO, di Menna ME, Jacobs SWL, Garthwaite I, Lane GA, Prestidge RA, Marshall SL, Wilkinson HH, Schardl CL, Ball OJP and Latch GCM (1998) Endophytic fungi in Indigenous Australasian grasses associated with toxicity to livestock. Appl. Environ. Microbiol. 64:601-606.

Onions AHS, Allsopp D and Eggins HOW (1981) Smith's introduction to industrial mycology. 7th ed. Edward Arnold, London. 398 pp.

Pereira JO, Azevedo JL and Petrini O (1993) Endophytic fungi of Stylosanthes: a preliminary study. Mycologia 85:362-364.

Pereira JO, Vieira MLC and Azevedo JL (1999) Endophytic fungi from Musa acuminata and their reintroduction in axenic plants. World J. Microbiol Biotechnol 15:43-46.

Petrini O (1986) Taxonomy of endophytic fungi of aerial plant tissues. In Fokkema N.J. and Heuvel J. van den (eds) Microbiology of the Phyllosphere. Cambridge University Press, Cambridge, pp 175-187.

Petrini O (1991) Fungal endophytic of tree leaves. In: Andrews J. and Hirano SS (eds) Microbial ecology of leaves. Spring Verlag, pp 179-197.
Pinto LSRC, Azevedo JL, Pereira JO, Vieira MLC and Labate CA (2000) Symptomless infection of banana and maize by endophytic fungi impairs photosynthetic efficiency. New Phytol. 147:609-615.

Pontecorvo G, Roper JA, Hemmons LM, McDonald KD and Bufton AWJ (1953) The genetics of Aspergillus nidulans. Advances in Genetics 5:141-238.

Punithalingam E (1974). Studies on Sphaeropsidales in culture II. Mycological Papers 136:1-9.

Raeder U and Broda P (1985) Rapid preparation of DNA from filamentous fungi. Lett. Appl. Microb. 1:17-20.

Robbs CF and Bittencourt AM (1995) A mancha preta dos frutos: um dos fatores limitantes à produção citrícola do estado do Rio de Janeiro. Comunicado Técnico, CTAA-EMBRAPA, 19:1-5.

Rodrigues KF (1994) The foliar fungal endophytes of the Amazonian palm Euterpe oleracea. Mycologia 86:376-385.

Rodrigues KF and Dias-Filho MB (1996) Fungal Endophytes in the tropical grasses Brachiaria brizantha cv. Marandu and B. humidicola. Pesq. Agropec. Bras. 31:905-909.

Rohlf FJ (1988) NTSYS-PC Numerical taxonomy and multivariate analysis system. Exeter Publishing, New York. 298 pp.

Sivanesan A (1984) The bitunicate Ascomycetes and their anamorphus. J. Cramer., Vaduz, Germany, 701 pp.

Strobel GA and Long DM (1998) Endophytic microbes embody pharmaceutical potential. ASM News 64:263-268.

Tedford EC, Jaffee BA, and Muldoon AE (1994) Variability among isolates of the nematophagous fungus Hirsutella rhossiliensis. Mycol. Res. 98:1127-1136.

Tsai YP (1981) Citrus Black Spot control in Taiwan. Proc. Internat. Soc. Citric. 1:344-346.

Van der aa, HA (1973) Studies in Phyllosticta I. Studies in Mycology $5: 1-105$.

Von Arx JA (1974) The Genera of fungi sporulating in pure culture. 2 ed. J. Cramer, Vaduz, Germany. 351 pp.

Yap IV and Nelson RJ (1996) Winboot: a program for performing bootstrap analysis of binary data to determine the confidence limits of UPGMA-based dendrograms. IRRI discussion paper, $14.22 \mathrm{pp}$. 